\title{
Penerapan Pola Tanam Tumpangsari Dalam Pengelolaan Hama Tanaman Kacang Hijau (Phaseolus radiatus L.)
}

\author{
Lastri Siagian*, Wilyus dan Fuad Nurdiansyah \\ Jurusan Agroekoteknologi Fakultas Pertanian, Universitas Jambi \\ Jl. Raya Jambi - Ma. Bulian KM. 15 Kampus Pinang Masak, Mendalo Darat, 36361 \\ Email : Lastrisiagian34@yahoo.co.id (*Penulis untuk korespondensi)
}

\begin{abstract}
ABSTRAK
Kacang hijau (Phaseolus radiatus L) umumnya dimanfaatkan untuk kebutuhan pangan dan industri pakan. Saat ini permintaan pasar akan kacang hijau terus meningkat, sedangkan produksinya terus menurun. Salah satu faktor yang menyebabkan penurunan produksi kacang hijau adalah serangan hama. Petani umumnya melakukan pengendalian hama dengan menggunakan pestisida sintetik tanpa mempertimbangkan dampak negatif terhadap lingkungan dan konsumen. Sitem tanam tumpangsari merupakan salah satu cara budidaya yang ramah lingkungan yang berpotensi menurunkan kerusakan tanaman akibat hama, akan tetapi informasi cara budidaya tersebut pada tanaman kacang hijau masih terbatas. Rancangan percobaan yang digunakan dalam penelitian adalah Rancangan Acak Kelompok (RAK) yang dikelompokkan berdasarkan kemiringan lahan dan terdiri dari 4 perlakuan yaitu: P1 (Monokultur kacang hijau (kontrol)); P2 (Tumpangsari kacang hijau + bawang daun); P3(Tumpangsari kacang hijau + bunga matahari); P4 (Tumpangsari kacang hijau+bunga matahari + bawang daun). Variabel pengamatan pada penelitian adalah kelimpahan jenis serangga, fungsi ekologi serangga, persentase tanaman terserang dan produksi kacang hijau. Data dianalis dengan analisis ragam dan dilanjutkan dengan uji lanjut tukey. Hasil penelitian menunjukan bahwa bahwa nilai kelimpahan serangga pada semua perlakuan tidak berbeda, akan tetapi persentase serangan hama terendah terdapat pada perlakuan $\mathrm{P} 4$, sedangkan jumlah populasi musuh alami, penyerbuk dan produksi tertinggi terdapat pada perlakuan $\mathrm{P} 4$.
\end{abstract}

Kata kunci: Tumpangsari, kacang hijau, pengelolaan hama,

\section{PENDAHULUAN}

Kacang hijau (Phaseolus radiatus L) umumnya dimanfaatkan untuk kebutuhan pangan dan industri pakan (Sumarji 2013). Kacang hijau merupakan bahan makanan yang dapat menggantikan beras sebagai bahan pangan di Indonesia (Sumarji, 2013). Selain itu, kacang hijau juga berperan dalam menaikan devisa negara, karena berpeluang untuk memasok sebagian permintaan pasar dunia (Wibowo, 2013). Saat ini permintaan pasar akan kacang hijau terus meningkat, sedangkan produksinya terus menurun (Barus dkk., 2015). Badan Pusat Statistik Provinsi Jambi melaporkan bahwa setiap tahunnya produksi 
kacang hijau di Provinsi Jambi selalu menurun. Ini dibuktikan dengan produksi kacang hijau tahun 2012 sebesar 381 ton, tahun 2013 sebesar 262 ton, tahun 2014 sebesar 168 ton dan tahun 2015 sebesar 129 ton (BPS, 2016).

Salah satu faktor yang menyebabkan penurunan produksi kacang hijau adalah serangan hama (Fauzi dan Muda 2012). Tanaman kacang hijau berinteraksi dengan 85 jenis spesies hama dan di antaranya terdapat beberapa hama utama yaitu lalat bibit Ophiomya phaseoli Tryon (Diptera: Agromyzidae), kepik hijau Nezara viridula Linnaeus. (Hemiptera: Pentatomidae), kepik cokelat Riptortus linearis Fabr. (Hemiptera: Alydidae), kutu daun Aphis craccivora Koch (Hemiptera: Aphididae), Helicoverpa armigera Huebner (Lepidoptera: Noctuidae), ulat penggerek polong Maruca testulalis Geyer (Lepidoptera: Pyralidae), dan Etiella zinckenella Treitschke (Lepidoptera: Pyralidae) (Talekar, 1998).

Penurunan produksi akibat serangan hama pada tanaman kacang hijau bervariasi tergantung jenis hama yang menyerang dan juga umur tanaman. Kehilangan hasil diakibatkan karena serangan $M$. testulalis mencapai $60 \%$ tergantung daerah dan cuaca ditempat (Macfoy dkk, 1983). Kepik coklat (R. linearis) dan kepik hijau (N. viridula) dapat menyebabkan kehilangan hasil mencapai $80 \%$ jika tidak dilakukan usaha pengendalian (Prayogo, 2013). Gangwar dan Thakur (1988) dalam Biswas dan Islam (2012) melaporkan bahwa serangan hama penggulung daun (L. Indicata) pada tanaman berumur tiga minggu dapat mencapai 70 - 90\% dengan tingkat kehilangan hasil mencapai 22\%. Hasil pengamatan gejala serangan pada kotiledon menunjukkan pada umur 10 hari setelah tanam (hst) tingkat serangan lalat bibit mencapai 29,9\% dan menjadi 65\% pada umur 13 hst (Ginting, 2009).

Petani umumnya melakukan pengendalian hama dengan menggunakan pestisida sintetik karena dianggap lebih efektif untuk mengendalikan hama, akan tetapi tanpa mempertimbangkan dampak negatif terhadap lingkungan. Keuntungan dari penggunaan pestisida sintetik dalam pengendalian hama adalah pestisida sintetik mudah didapat dan diaplikasikan oleh petani (Sofia, 2001). Akan tetapi dampak negatif dari penggunaan pestisida sintetik yaitu hama menjadi resisten dan resurgensi, kematian musuh alami, timbulnya hama baru, akumulasi bahan kimia pada produk pertanian, dapat merusak lingkungan, dan menyebabkan keracunan bagi konsumen produk pertanian (Sudarmo, 1991).

Penurunan produksi atau bahkan gagal panen diakibatkan oleh serangan hama dapat dihindari dengan menerapkan sistem tanam tumpangsari (Sjam dkk., 2011). Tumpangsari adalah penggabungan dua tanaman sekaligus atau lebih di lahan pertanian (Puspa Lorina 
dkk., 2015). Penggabungan dapat dilakukan dengan menanam bermacam-macam tanaman diantara bedengan, disekitar bedengan atau pun melingkari bedengan. (Sjam dkk., 2011). Sistem tanam tumpangsari juga dapat mengurangi kegagalan panen (Cahyono, 2005). Keuntungan yang lebih pada hasil telah diketahui pada banyak sistem tumpangsari, termasuk jagung-kedelai, kedelai-sorgum, jagung-kacang panjang (Rezvani dkk, 2011). Tumpangsari juga bermanfaat dalam peningkatan musuh alami dalam pengendalian hama tanaman (Carruthers dkk, 2000).

Tumpangsari berperan dalam meningkatkan keanekaragaman serangga dan menjaga kestabilan agroekosistem. Salah satu kestabilan agroekosistem ditunjukan dengan keseimbangan antara serangga hama dengan serangga yang berpotensi sebagai musuh alami sehingga kerusakan tanaman dapat berkurang di bawah ambang ekonomi (Untung, 2006). Menurut Pramudyani dkk (2016) bahwa dalam budidaya cabai menggunakan bawang daun sebagai tanaman sela lebih menguntungan dibandingkan dengan sistem pertanaman monokultur cabai. Produksi cabai yang ditumpangsarikan dengan bawang daun mencapai 12 ton/ha dibandingkan dengan monokultur hanya 8 ton/ha (Pramudyani dkk., 2016). Tanaman sela bawang daun ternyata dapat mengurangi serangan hama sehingga pada sistem pertanaman tumpangsari bawang daun memiliki kerusakan daun yang lebih rendah dibandingkan sistem pertanaman monokultur (Pramudyani dkk., 2016). Produksi kentang juga dapat ditingkatkan dengan menumpangsarikan dengan bawang daun, karena dapat menekan populasi dan intensitas serangan hama (Setiawati dkk., 2005).

Berdasarkan pengetahuan dan hasil pencarian literatur selama ini informasi budidaya tumpangsari kacang hijau dengan bawang daun dan bunga matahari sangat terbatas sehingga berdasarkan hal tersebut di atas maka penulis tertarik melakukan penelitian tentang "Penerapan Pola Tanam Tumpangsari dalam Pengelolaan Hama Tanaman Kacang Hijau (Phaseolus radiatus L.) ".

Penelitian ini bertujuan untuk mengetahui pengaruh penerapan pola tanam tumpangsari terhadap pengelolaan hama, peningkatan peranan musuh alami (predator dan parasitoid), peningkatan keanekaragaman serangga agar tercapai kestabilan agroekosistem dan juga terhadap produksi tanaman kacang hijau.

\section{METODE PENELITIAN}

Metode yang digunakan dalam penelitian ini Rancangan Acak Kelompok (RAK) yang dikelompokkan berdasarkan kemiringan lahan dan terdiri dari 4 perlakuan yaitu: P1: 
Monokultur kacang hijau (kontrol); P2: Tumpangsari kacang hijau + bawang daun; P3: Tumpangsari kacang hijau + bunga matahari; P4: Tumpangsari kacang hijau + bunga matahari + bawang daun. Setiap perlakuan diulang sebanyak 7 kali. Pengambilan sampel serangga dilakukan menggunakan perangkap yellow pan. Pengambilan sampel dilakukan pada tiap petak sebanyak 6 kali dengan interval waktu 2 minggu. Selanjutnya dilakukan identifikasi di laboratorium hama tanamanan Fakultas Pertanian Universitas Jambi. Selanjutnya dihitung kelimpahan serangga, fungsi ekologi serangga dalam ekosistem, persentase tanaman terserang hama dan produksi kacang hijau. Data dianalisis secara statistik dengan sidik ragam selanjutnya untuk melihat perbedaan perlakuan dilakukan uji lanjut tukey.

\section{HASIL}

\section{Keanekaragaman Jenis Serangga}

Hasil pengamatan selama penelitian menggunakan perangkap yellow pan ditemukan 64 famili dan 85 morfospesies dengan jumlah keseluruhan 5.257 dan famili yang mendominasi adalah Cicadellidae, Apidae dan Aphididae. Keanekaragaman jenis serangga pada keempat lahan penelitian tergolong sangat stabil. Nilai indeks kemerataan pada keempat lahan penelitian tergolong tinggi. Nilai indeks kekayaan jenis pada keempat lahan penelitian tergolong sedang. Hasil analisa keanekaragaman serangga disajikan pada Tabel 1.

Tabel 1. Keanekaragaman jenis serangga pada berbagai pola tanam kacang hijau $7-79$ hst.

\begin{tabular}{cccc}
\hline Perlakuan & $\mathrm{H}^{\prime}$ & $\mathrm{R}$ & $\mathrm{e}^{\prime}$ \\
\hline P1 & 2,20 & 4,11 & 0,74 \\
P2 & 2,36 & 4,20 & 0,76 \\
P3 & 2,44 & 4,72 & 0,77 \\
P4 & 2,52 & 4,74 & 0,79 \\
\hline
\end{tabular}

\section{Fungsi Ekologi Serangga}

\section{Rata- Rata Jumlah Populasi Serangga Herbivora}

Hasil penelitian menunjukan bahwa penerapan pola tanam kacang hijau tidak berpengaruh nyata terhadap rata - rata populasi serangga herbivora. Analisis statistik dan uji lanjut tukey disajikan pada Grafik 1 . 


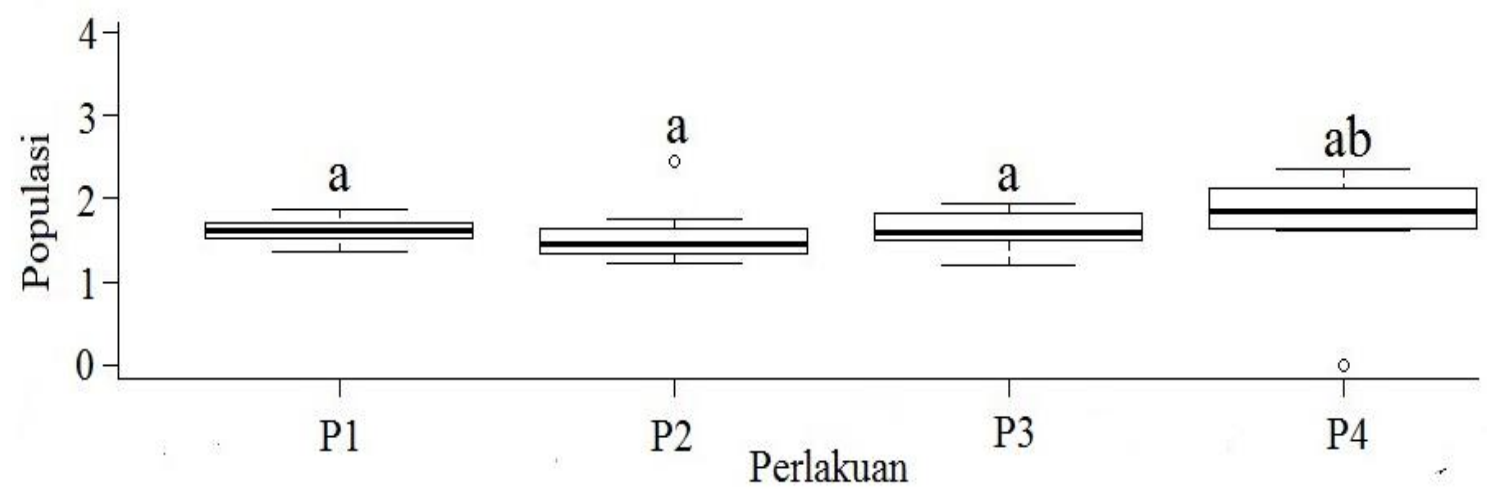

Grafik 1. Rata- rata jumlah populasi serangga herbivora (ekor/perangkap) pada berbagai perlakuan. Huruf yang sama tidak berbeda nyata menurut uji tukey.

Grafik 1 menunjukan bahwa penerapan pola tanam tidak berpengaruh nyata terhadap rata - rata jumlah populasi serangga herbivora sesuai dengan hasil analisis ragam dengan nilai signifikan ( $p$-value) 0,11. Rata - rata populasi hama tertinggi terdapat pada P4 sebesar 1,91 dengan Standar Eror (SE) sebesar 0,15.

\section{Rata-Rata Populasi Musuh Alami}

Hasil penelitian menunjukan bahwa penerapan pola tanam kacang hijau berpengaruh nyata terhadap rata- rata populasi musuh alami. Analisis statistik dan uji lanjut tukey disajikan pada Grafik 2.

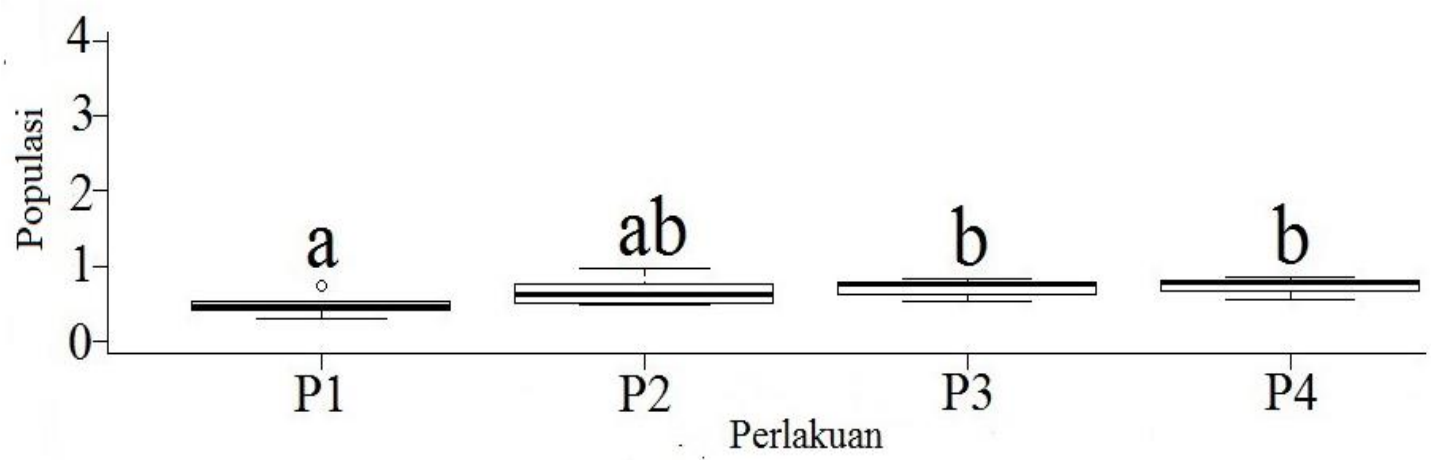

Grafik 2. Rata- rata jumlah populasi musuh alami (ekor/perangkap) pada berbagai perlakuan. Huruf yang sama tidak berbeda nyata menurut uji tukey.

Grafik 2 menunjukan bahwa penerapan pola tanam berpengaruh nyata terhadap rata- rata jumlah populasi musuh alami sesuai dengan hasil analisis ragam dengan nilai $p$ value sebesar 0,006. P1 bertendensi berbeda nyata dengan P2 sedangkan dengan P3 dan P4 berbeda nyata. Rata- rata jumlah populasi musuh alami tertinggi terdapat pada $\mathrm{P} 4$ sebesar 0,74 ekor dan SE sebesar 0,06. 


\section{Rata-Rata Jumlah Populasi Penyerbuk}

Hasil penelitian menunjukan bahwa penerapan pola tanam kacang hijau berpengaruh nyata terhadap rata- rata populasi penyerbuk dengan hasil analisis ragam dengan $p$-value 0.002 . P1 tidak berbeda nyata dengan $\mathrm{P} 2$ tetapi bertendensi berbeda nyata dengan P3 dan berbeda nyata dengan P4. Rata- rata jumlah populasi penyerbuk tertinggi terdapat pada P4 sebesar 1,38 ekor dan SE sebesar 0,10. Analisis statistik dan uji lanjut tukey disajikan pada Grafik 3.

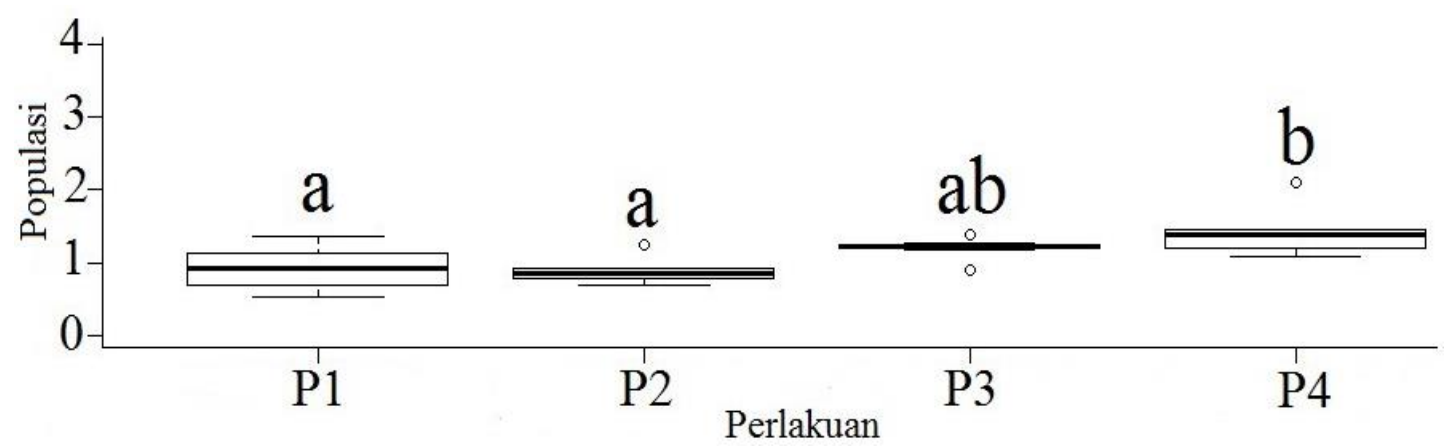

Grafik 3. Rata- rata jumlah populasi penyerbuk (ekor/perangkap) pada berbagai habitat. Huruf yang sama tidak berbeda nyata menurut uji tukey.

\section{Persentase Serangan Hama}

Hasil penelitian menunjukan bahwa penerapan pola tanam kacang hijau berpengaruh nyata terhadap persentase serangan lalat bibit, kutu daun, penggulung daun, penggerek polong dan pengisap polong. Hasil analisis statistik dan uji lanjut tukey dapat dilihat pada Tabel 2.

Tabel 2. Penerapan pola tanam kacang hijau terhadap persentase serangan hama tanaman kacang hijau.

\begin{tabular}{lcccc}
\hline \multirow{2}{*}{\multicolumn{1}{c}{ Jenis }} & \multicolumn{4}{c}{ Persentase Serangan } \\
\cline { 2 - 5 } & $\mathrm{P} 1$ & $\mathrm{P} 2$ & $\mathrm{P} 3$ & $\mathrm{P} 4$ \\
\hline Agromyza phaseoli & $2,38 \mathrm{a}$ & $0,73 \mathrm{a}$ & $1,28 \mathrm{a}$ & $0,54 \mathrm{a}$ \\
Aphis craccivora & $22,71 \mathrm{a}$ & $15,57 \mathrm{bc}$ & $18,86 \mathrm{~b}$ & $12,09 \mathrm{c}$ \\
Lamprosema indicata & $3,03 \mathrm{a}$ & $0,91 \mathrm{~b}$ & $2,01 \mathrm{ab}$ & $0,91 \mathrm{~b}$ \\
Penggerek polong & $3,42 \mathrm{a}$ & $1,15 \mathrm{c}$ & $2,25 \mathrm{~b}$ & $1,21 \mathrm{c}$ \\
Pengisap polong & $3,38 \mathrm{a}$ & $1,18 \mathrm{c}$ & $2,37 \mathrm{~b}$ & $1,28 \mathrm{c}$ \\
\hline
\end{tabular}

Keterangan : Angka pada tiap baris yang diikuti dengan huruf yang sama tidak berbeda nyata menurut uji tukey taraf $5 \%$.

Dari Tabel 2 terlihat bahwa persentase serangan lalat bibit tidak berbeda nyata. Persentase serangan pada kutu daun P1 berbeda nyata dengan P2, P3 dan P4. Persentase serangan penggulung daun P1 berbeda nyata dengan P2 dan P4 tetapi tidak berbeda nyata 
dengan P3. Persentase serangan penggerek polong P1 berbeda nyata dengan P2, P3 dan P4. P4 berbeda nyata dengan P3 dan P1 tetapi tidak berbeda nyata dengan P2. Persentase serangan pengisap polong P1 berbeda nyata dengan P2, P3 dan P4. P4 berbeda nyata dengan P3 dan P1 tetapi tidak berbeda nyata dengan P2.

\section{Produksi}

Penerapan pola tanam tumpangsari kacang hijau berpengaruh nyata terhadap produksi kacang hijau. P1 berbeda nyata dengan P2, P3 dan P4. P2 berbeda nyata dengan P1 dan P4 tetapi tidak berbeda nyata dengan P3. P3 berbeda nyata dengan P1 dan P4 tetapi tidak berbeda nyata dengan P2. P4 berbeda nyata dengan P2, P3 dan P1. Produksi terendah terdapat pada P1 yaitu sebesar 308,57 gram dan produksi tertinggi terdapat pada P4 yaitu sebesar 549,29 gram. Analisis statistik dan uji lanjut tukey disajikan pada Tabel 3.

Tabel 3. Pengaruh penerapan pola tanam kacang hijau terhadap produksi kacang hijau.

Perlakuan Produksi (gram)

\begin{tabular}{ll}
\hline P1 & $308,57 \mathrm{a}$ \\
P2 & $419,28 \mathrm{~b}$ \\
P3 & $395,71 \mathrm{~b}$ \\
P4 & $549,28 \mathrm{c}$ \\
\hline
\end{tabular}

Keterangan: Angka pada tiap kolom yang diikuti dengan huruf yang sama tidak berbeda nyata menurut uji tukey taraf $5 \%$.

\section{PEMBAHASAN}

Berdasarkan hasil penelitian kelimpahan jenis serangga yang paling tinggi terdapat padapola tanam tumpangsari dengan bawang daun dan bunga matahari. Hal ini diduga karena tanaman tumpangsari lebih kompleks . Sesuai dengan penelitian Kamal, Yustian, dan Rahayu (2011) jenis dan populasi serangga sangat ditentukan oleh keragaman struktur habitat, keragaman jenis dan populasi akan tinggi jika keragaman struktur habitatnya meningkat. Menurut penelitian (Schellhorn dan V. L 1997) bahwa keragaman vegetasi dapat meningkatkan keragaman serangga herbivora dan karnivora. Keanekaragaman identik dengan kestabilan suatu ekosistem, yaitu jika keanekaragaman suatu ekosistem tinggi, maka kondisi ekosistem tersebut cenderung stabil (Odum 1993).

Penerapan pola tanam pada tanaman kacang hijau tidak berpengaruh nyata terhadap serangga herbivora. Hal ini diduga karena terdapat semak pada setiap habitat yang 
berfungsi sebagai inang alternatif pada hama famili Cicadellidae yang mendominasi di lahan tersebut. Sesuai dengan penelitian Karindah dkk (2011) menyatakan bahwa beberapa gulma dapat digunakan sebagai inang alternatif yang menyediakan mangsa alternatif dan tempat berlindung apabila tanaman utama tidak tersedia. Menurut Gusti (2014) semak dapat dijadikan sebagai inang alternatif bagi hama untuk melanjutkan proses hidupnya.

Penerapan pola tanam pada tanaman kacang hijau berpengaruh nyata terhadap musuh alami. Hal ini diduga karena adanya tanaman bunga matahari sebagai Refugia bagi musuh alami. Sesuai dengan penelitian (Afifah dkk., 2015) bahwa tanaman bunga matahari sebagai mikrohabitat memberikan pengaruh yang nyata terhadap rerata kelimpahan musuh alami dibandingkan dengan tanaman yang tidak memiliki tanaman bunga matahari. Menurut hasil penelitian Allifah dkk (2013) menunjukkan bahwa tanaman bunga matahari sebagai mikrohabitat berpengaruh nyata terhadap rerata kelimpahan musuh alami pada tiap periode. Menurut penelitian Hemanto dkk. (2014) menyatakan bahwa populasi musuh alami lebih tinggi pada pengelolaan hama terpadu berbasis rekayasa ekologi yang ditanami dengan bunga matahari dibandingkan dengan pengelolaan hama terpadu konvensional tanpa bunga matahari.

Penerapan pola tanam pada tanaman kacang hijau berpengaruh nyata terhadap penyerbuk. Hal ini diduga karena adanya tanaman bunga matahari pada P4 dan P3 berfungsi sebagai penarik serangga penyerbuk. Menurut penelitian yang dilakukan oleh Wardhani dkk (2013) menyebutkan bahwa jumlah serangga yang tertarik pada tanaman bunga matahari lebih tinggi dibandingkan pada lahan yang tidak dikombinasikan dengan tanaman bunga matahari. Menurut penelitan Sejati (2010) serangga polinator banyak berkunjung pada tanaman padi yang memiliki tanaman bunga matahari.

Penerapan pola tanam tumpangsari berpengaruh nyata terhadap persentase serangan hama. Persentase serangan hama pada pola tanam tumpangsari lebih rendah dibandingkan dengan pola tanam monokultur. Hal ini diduga karena pada pola tanam tumpangsari terdapat bawang daun yang mempunyai senyawa repellent untuk hama dan tanaman bunga matahari yang menjadi Refugia terhadap serangga. Penggunaan tanaman tumpangsari meningkatkan keanekaragaman tanaman di lapangan yang dapat menekan serangan hama dan meningkatkan kinerja musuh alami Nirmayanti dkk (2015). Menurut penelitian Kurniawati (2015) tumbuhan berbunga dapat meningkatkan serangga hama dan serangga musuh alami. Menurut Johan (2011) menyatakan bahwa populasi serangga herbivora yang tinggi akan diimbangi oleh populasi musuh alami yang tinggi sehingga ekosistem pertanian tersebut stabil. 
Penerapan pola tanam pada tanaman kacang hijau berpengaruh nyata terhadap produksi kacang hijau. Produksi kacang hijau pada pola tanam tumpangsari lebih tinggi dibandingkan dengan pola tanam monokultur. Hal ini diduga karena pada pola tanam tumpangsari dapat menaikkan produksi tanaman karena kurangnya kerusakan hama dan tingginya musuh alami. Berdasarkan penelitian (Pramudyani, Qomariah, dan Yassin, 2016) tanaman cabai yang ditumpangsarikan dengan tanaman bawang daun dapat mengurangi keberadaan hama. Aroma dari bawang daun ini dapat menimbulkan bau yang tidak disukai hama sehingga dapat mengurangi tingkat kerusakan dan menaikkan produksi tanaman. Berdasarkan penelitian (Kurniawati dan Martono 2015) penanaman tanaman Refugia pada lahan persawahan dapat mempertahankan keberadaan musuh alami di dalam ekosistem pertanian sehingga produksi meningkat dibandingkan dengan pola tanam monokultur.

\section{KESIMPULAN}

Berdasarkan hasil penelitian nilai indeks keanekaragaman Shannon - Wienner pada lahan monokultur dan tumpangsari tergolong tinggi, kekayaan jenis serangga pada monokultur dan tumpangsari tergolong sedang dan nilai indeks kemerataan serangga pada monokultur dan tumpangsari tergolong tinggi. Lahan tumpangsari kacang hijau dengan bawang daun dan bunga matahari memiliki musuh alami, penyerbuk dan produksi yang paling tinggi. Serta serangan hama terendah terdapat perlakuan tumpangsari kacang hijau dengan bawang daun dan bunga matahari.

\section{UCAPAN TERIMA KASIH}

Penulis mengucapkan terima kasih kepada Bapak Dr. Ir. Wilyus, M.Si dan Bapak Fuad Nurdiansyah, S.P., M.PlaHBio, Ph.D yang selalu membimbing dalam penulisan skripsi ini. Penulis juga mengucapkan terima kasih kepada semua pihak yang membantu dalam pelaksanaan penelitian ini.

\section{DAFTAR PUSTAKA}

Afifah, L, P. Hidayat, D. Buchori, dan B. T. Rahardjo. 2015. "Pengaruh Perbedaan Pengelolaan Agroekosistem Tanaman Terhadap Struktur Komunitas Serangga Pada Pertanaman Kedelai Di Ngale, Kabupaten Ngawi, Jawa Timur." Jurnal Hama Dan Penyakit Tumbuhan Tropika 15 (1):53-64.

Allifah dkk. 2013. Refugia sebagai mikrohabitat untuk meningkatkan Peran musuh alami di lahan pertanian. Malang. Prosiding FMIPA Universitas Pattimura 2013 ISBN: 978-602-97522-0-5. 
Badan Pusat Statistik. 2016. Jambi dalam Angka 2016. Badan Pusat Statistik Provinsi Jambi. Jambi.

Barus, Wan Arfiani, Hadriman Khair, and Muhammad Anshar Siregar. 2015. "Respon Pertumbuhan Dan Produksi Kacang Hijau (Phaseolus Radiatus L.) Akibat Penggunaan Pupuk Organik Cair Dan Pupuk Tsp." Jurnal IlmuPertanian" Agrium" 19 (1).

Biswan, G. C and Rabiul Islam.2012. Infestation And Management Of The Leaf Roller (Lamprosema indicata F) In Soybean. Bangladesh J. Agril. Res. 37 (1) : 19-25.

Cahyono. 2005. Bawang Daun, Teknik Budidaya dan Analisis Usaha Tani. Kanisius. Yogyakarta.

Carruthers, K., B. Prithiviraj, Q. Fe, D. Cloutier, R. C. Martin, and D. L. Smith. 2000. "Intercropping Corn with Soybean, Lupin and Forages: Yield Component Responses." European Journal of Agronomy 12 (2):103-115.

Fauzi, and Muda. 2012. Budidaya Tanaman Kacang Hijau. Yogyakarta: Kanisius.

Ginting Y F. 2009. Perkembangan Lalat Bibit Ophiomyia phaseoli Try. (Diptera: Agromyzidae) Pada Tanaman Kedelai. Skripsi Institut Pertanian Bogor, Bogor.

Gusti. 2014. Manfaat gulma bagi serangga herbivora. Yogyakarta

Johan. 2011. Kelimpahan Hama Dan Musuh Alami Serta Pengaruh Perlakuan Insektisida Pada Tanaman Kacang Panjang (Vigna Sinensis L.) Fase Generatif. Skripsi. Institut Pertanian Bogor. Bogor.

Kamal, Mustafa, Indra Yustian, and Sri Rahayu. 2011. "Keanekaragaman Jenis Serangga Di Gua Putri Dan Gua Selabe Kawasan Karst Padang Bindu, OKU Sumatera Selatan." Jurnal Penelitian Sains 14 (1).

Karindah dkk. 2011. Ketertarikan Anaxipha longipennis Serville (Orthoptera: Gryllidae) terhadap Beberapa Jenis Gulma di Sawah sebagai Tempat Bertelur.Universitas Brawijaya. Malang. J. Entomologi Indonesia. 1, Vol. 8, No. 1, hal 27-35

Kurniawati, Nia, and Edhi Martono. 2015. "Peran Tumbuhan Berbunga Sebagai Media Konservasi Serangga Musuh Alami The Role Of Flowering Plants In Conserving Arthropod Natural Enemies." Jurnal Perlindungan Tanaman Indonesia 19 (2):53-59.

Macfoy,C. A, Z. A. Dabrowski Dan Okech. 1983. Studies On Legume Pod Borer, Maruca testulalis (Geyer)-Iv. Cowpea Resitance To Oviposition And Larva Feeding Insect Sci. Applic. 4(12): 147-145.

Nirmayanti F, G Mudjiono dan S Karindah. 2015. Pengaruh beberapa jenis tanaman pendamping terhadap hama Phyllotreta striolata F. (Coleoptera : Chrysomelidae) pada budidaya sawi hijau organik. Jurnal HPT 3(2): 69-75

Odum, Eugene P. 1993. Dasar- Dasar Ekologi. Odum. Yogyakarta: Gadjah Mada University Press. 
Pramudyani, Lelya, R. Qomariah, and M. Yassin. 2016. "Tumpangsari Tanaman Cabai Merah Dengan Bawang Daun Menuju Pertanian Ramah Lingkungan.”

Prayogo. Y. 2013. Patogenesitas Cendawan Entomopatogen Beauveria bassiana (Deuteromycota: Hyphomycetes) pada berbagai stadia kepik hijau (Nezera viridula L.) J. HPT tropika. vol.13 (1) : 75-86. Malang.

Puspa. L, M. Dianucik, S. Sitawati, dan K. P. Wicaksono. 2015. "Studi Sistem Tumpangsari Brokoli (Brassica Oleracea L.) Dan Bawang Prei (Allium Porrum L.) Pada Berbagai Jarak Tanam.” Jurnal Produksi Tanaman 3 (7).

Rezvani. 2013. Tumpangsari Tanaman Pangan dengan Hortikultura untuk Meningkatkan Produksi. Skripsi. Universitas Negeri Malang. Malang

Schellhorn, N. S, and Sork V. L. 1997. Namics and Crop Yield in Collards, Brassica Oleraceae (Brassicaceae). Oecologia 111: 233-240. Shiva, V. 19. Oecologia $111: 223-240$.

Sejati. 2010. Studi jenis dan populasi serangga- serangga yang berasosiasi dengan tanaman berbunga pada petanaman padi. universitas sebelas maret. surakarta.

Setiawati., dkk. 2005. "Pengendalian Kutu Kebul Dan Nematoda Parasitik Secara Kultur T Eknik Pada T Anaman Kentang" 15(4):288-289.

Sjam, Sylvia, Untung Surapati, Ade Rosmana, and Sulaeha Thamrin. 2011. "Teknologi Pengendalian Hama Dalam Sistem Budidaya Sayuran Organik."

Sofia, Diana. 2001. "Pengaruh Pestisida Dalam Lingkungan Pertanian." Bandung Sudarmo, Subiyakto. 1991. Pestisida. Kanisius.

Sumarji. 2013. "Laporan Kegiatan Penyuluhan Teknik Budidaya Tanaman Kacang Hijau (Vigna Radiata (L) Wilczek).”

Talekar, NS. 1998. "Insect Pests of Mungbean and Their Control. p.101-187 in: Multilocation Testing on Mungbean Germplasm Training Course: Lecture Handout. Nakhon Pathom: Kasetsart University. AVRDC Staff Publication. SB317.M85A7."

Untung, K. 2006. Pengantar Pengelolaan Hama Terpadu. Yogyakarta: Gadjah Mada University Press.

Wardani, F.S., A.S. Leksono, B. Yanuwiadi. 2013. Efek Blok Refugia (Ageratum conyzoides, Ageratum houstonianum, Commelina diffusa) Terhadap Pola Kunjungan Serangga di Perkebunan Apel Desa Poncokusumo, Malang. Jurnal Biotropika | Vol. 1 No 22013.

Wibowo, A. Suryo. 2013. "Pengaruh Pupuk Magnesium (Mg) Terhadap Produksi Dan Serapan Hara N, P, K, Ca, Mg Tanaman Kacang Hijau Di Latosol Darmaga. 